\title{
State Immunity and Serious Violations of Human Rights: Judgment No. 238 of 2014 of the Italian Constitutional Court Seven Years On
}

\author{
Carlo Focarelli \\ Department of Political Science, University of Roma Tre, Rome, Italy \\ carlo.focarelli@uniromas.it
}

\begin{abstract}
On 3 February 2021, the US Supreme Court affirmed the ICJ's Jurisdictional Immunities of the State Judgment of 2012-according to which "a State is not deprived of immunity by reason of the fact that it is accused of serious violations of international human rights law" - adopting, thus, a position opposite to that taken by the Italian Corte Costituzionale in its well-known Judgment No. 238 of 2014. Based on a realistconstructivist theoretical approach to international law, this article argues that the only plausible legal perspective justifying Judgment No. 238 is a dynamic one. However, the Corte Costituzionale has substantially failed to argue the plausibility of the expected change in existing international law that it wished to promote for the future. To take its intended big leap realistically and successfully, the Italian position would have deserved a sounder theoretical analysis of international law and of the world system in which the latter is meant to work.
\end{abstract}

\section{Keywords}

state immunity - human rights - legal constructivism

On 3 February 2021, the US Supreme Court noted in Federal Republic of Germany et al. v. Philipp et al. that "[a]s the International Court of Justice recently ruled [in its 2012 Jurisdictional Immunities of the State Judgment] when considering 
claims brought by descendants of citizens of Nazi-occupied countries, 'a State is not deprived of immunity by reason of the fact that it is accused of serious violations of international human rights law"'.1 The Supreme Court also pointed out that "[w]e have recognized that United States law governs domestically but does not rule the world", and that "[w]e interpret the FSIA [i.e. the US Foreign Sovereign Immunities Act of 1976, concerning foreign States' jurisdictional immunity] as we do other statutes affecting international relations: to avoid, where possible, producing friction in our relations with [other] nations and leading some to reciprocate by granting their courts permission to embroil the United States in expensive and difficult litigation".

A first-instance Judgment issued by the Seoul District Court a few weeks earlier, and pulling in the opposite direction, is also noteworthy. On 8 January 2021, the Korean court denied immunity to Japan and condemned it for "crimes against humanity", ordering the country to pay 100 million Korean won (or approximately 77,800 euros) each to 12 women who were forced to work in wartime brothels, or so called "comfort stations", operated by the Japanese Empire during Second World War. The Seoul District Court also granted provisional execution of the order for compensation, a fact which allows the immediate seizure of the Japanese government's assets in South Korea. According to the Court, Japan's conduct constituted "a crime against humanity that was systematically, deliberately and extensively committed by Japan in breach of international norms", and "even if it was a country's sovereign act, State immunity cannot be applied as it was committed against our citizens on the Korean peninsula that was illegally occupied by Japan". The Japanese government stated that, by denying the principle of sovereign immunity and granting relief to the plaintiffs, the Korean Court violated international law, and it described the judgement as "absolutely unacceptable", urging the Korean government to "take appropriate measures to correct violations of international law". In turn, the Korean Ministry of Foreign Affairs released a statement in support of the Seoul District Court's decision, and it declared that it will make every effort to recover the dignity and honour of the victims. ${ }^{3}$ However, on 20 April 2021, the same Court (although sitting in a different composition)

1 ICJ, Jurisdictional Immunities of the State (Germany v. Italy: Greece intervening), Judgment of 3 February 2012, ICJ Reports, 2012, p. $99 \mathrm{ff}$.

2 Supreme Court (United States), Federal Republic of Germany et al. v. Philipp et al., Judgment of 3 February 2021, pp. 13-15, quoting Supreme Court (United States), Kiobel v. Royal Dutch Petroleum Co., Judgment of 17 April 2013, p. 115, itself quoting Supreme Court (United States), Microsoft Corp. v. AT\&T Corp., Judgment of 30 April 2007, p. 454.

3 See Agrawal, "South Korea Court Orders Japan to Compensate Sex Abuse Victims from Wartime Brothels", Jurist, 9 January 2021, available at: <https://www.jurist.org/news/2021/o1/ south-korea-court-orders-japan-to-compensate-sex-abuse-victims-from-wartime-brothels/>. 
dismissed the victims' request to implement the seizure of Japan's assets in South Korea. Furthermore, on 21 April 2021, in relation to a similar claim for compensation raised by 20 other women, the Seoul District Court recognized Japan's immunity from South Korea's civil jurisdiction on the basis of customary international law, underlining that "[i]f [the court] accepts an exception in state immunity, a diplomatic clash is inevitable in the process of the ruling and enforcing it", and that "[r] esolution of the comfort women issue should be made through diplomatic discussions". ${ }^{4}$

In 2014, in relation to a similar issue, i.e. that of the possible denial of jurisdictional immunity to foreign States that are accused of serious human rights violations-namely, in that case, Germany, accused before Italian courts of serious violations of human rights during the Nazi occupation of Italy in 19431945 - the Italian Corte Costituzionale, in its well-known Judgment No. 238 of 22 October 2014 (hereinafter, "Judgment No. 238"), 5 took a position opposite to the one just taken by the US Supreme Court. Judgement No. 238 has been extensively commented and, so far, substantially followed by Italian lower courts, despite it contrasts with the above-mentioned International Court of Justice (“ICJ") 2012 Judgment (hereinafter, "2012 ICJ Judgment”). Nonetheless, without indulging in the many questions that have so far already been discussed by others, a reappraisal of Judgment No. 238 may be useful, in light of the current trend of domestic supreme courts exemplified by the 2021 US Supreme Court Philipp Judgment and by Seoul District Court Judgment on so called "comfort women".

The Ferrini Saga and Judgment No. 238

Before addressing Judgment No. 238, a few steps back in time are helpful. As is well-known, in 2004 the Italian Corte di Cassazione took the view that Germany could be denied jurisdictional immunity, insofar as it was accused of serious violations of human rights committed by the Third Reich in 1943-1945

4 See yadAV, "South Korea Court Dismisses Suit for Compensation by Victims of Japanese Occupation Sexual Slavery", Jurist, 23 April 2021, available at <https://www.jurist.org/ news/2021/o4/south-korea-court-dismisses-suit-for-compensation-by-victims-of-japaneseoccupation-sexual-slavery/>.

5 The English translation is available at: <https://www.cortecostituzionale.it/documenti/ download/doc/recent_judgments/S238_2013_en.pdf >. The constitutional judges sitting for Judgment No. 238 were: Giuseppe Tesauro (President), Sabino Cassese, Paolo Maria Napolitano, Giuseppe Frigo, Alessandro Criscuolo, Paolo Grossi, Giorgio Lattanzi, Aldo Carosi, Marta Cartabia, Sergio Mattarella, Mario Rosario Morelli, Giancarlo Coraggio, Giuliano Amato. 
during the occupation of Italy. ${ }^{6}$ This ruling was affirmed in many subsequent decisions on the basis of a variety of reasons, one being the hierarchical superiority of the peremptory rules on human rights, when balanced against the customary international law rule on jurisdictional immunity. Most Italian scholars have wholeheartedly defended this "Ferrini-inspired" jurisprudence. ${ }^{7}$

For my part, since 2005 I have taken the position that the latter lacked legal basis in international law, and that both Italian courts and scholarship en masse were trying to present as "the law in force" what was, at best, a better law for the future. ${ }^{8}$ In my opinion, there was simply no practice supporting the Ferrini case law. This was also the position taken, a few years later, by the ICJ, in the above-mentioned 2012 ICJ Judgment on the case initiated by Germany in 2008. During the ICJ proceedings, the Italian government—which had, until then, always taken the side of Germany in domestic proceedings-found itself, all of a sudden, in the position of having to defend itself against Germany. It did so with no success. However, most Italian scholars continued to defend the domestic Ferrini jurisprudence by criticising the ICJ decision, which was labelled as "conservative".

In fact, the lower courts in Italy immediately found that the ICJ Judgment was self-executing within the Italian legal system, and they discontinued all ongoing proceedings against Germany by victims (or their descendants) who were seeking compensation for human rights violations committed by the Nazis in 1943-1945. Soon, the Corte di Cassazione itself followed suit, against its own stance adopted in the 2004 Ferrini Judgment, ruling in favour of the immediate and direct effect of the 2012 ICJ Judgment within the Italian legal system, and declaring that there was no need to raise a question of constitutionality. ${ }^{9}$ Moreover, to make sure that the courts complied with the ICJ Judgment, the

6 For facts, case law and references see FOCARELLI, International Law as Social Construct: The Struggle for Global Justice, Oxford, 2012, pp. 433-437; ID., Trattato di diritto internazionale, Torino, 2015, pp. 893-918.

7 For references see the previous note.

8 FoCARELli, "Denying Foreign State Immunity for Commission of International Crimes: The Ferrini Decision", International \& Comparative Law Quarterly, 2005, p. 951 ff.; ID., "Diniego dell'immunità giurisdizionale degli Stati stranieri per crimini, jus cogens e dinamica del diritto internazionale", RDI, 2008, p. 738 ff.; ID., "Immunité des États et jus cogens. La dynamique du droit international et la fonction du jus cogens dans le processus de changement de la règle sur l'immunité juridictionnelle des États étrangers", Revue Générale de Droit International Public, 2008, p. 761 ff.; ID., "Diniego dell'immunità alla Germania per crimini internazionali: la Suprema Corte si fonda su valutazioni 'qualitative", RDI, 2009, p. 363 ff.; ID., "Federal Republic of Germany v. Giovanni Mantelli and Others, Order No. 14201", American Journal of International Law, 2009, p. $122 \mathrm{ff}$.

9 Corte di Cassazione (Sez. I penale), Criminal proceedings against Albers and others, 9 August 2012, No. 32139; Corte di Cassazione (Sezioni Unite Civili), Frascà v. Federal Republic of 
government (re-adopting its previous pro-Germany stance, after the ICJ trial's parenthesis) proposed the creation of a legally-binding rule to make it obligatory for the Italian courts to comply with the 2012 ICJ Judgment, and the Parliament adopted it as Article 3 of Law No. 5 of 14 January 2013. At this stage, thus, Italy was bound to comply with both the international customary rule imposing the recognition of immunity to Germany and the ICJ Judgment. Within the Italian legal system, the former obligation was operative by virtue of Art. 10(1) of the Italian Constitution, ${ }^{10}$ while the latter by virtue of said Law No. 5 of 2013, as well as of Article 1 of Law No. 848 of 17 August 1957 giving effect to the UN Charter (including its Article 94 and the related obligation to comply with the ICJ Judgment).

However, in 2014 the Tribunale diFirenze asked the Italian Corte Costituzionale to review whether Italy's compliance with the 2012 ICJ Judgment was unconstitutional for breaching "fundamental principles" of the Italian Constitution, namely inviolable rights (Article 2 of the Italian Constitution $)^{11}$ and the right of access to court (Article 24 of the Italian Constitution), ${ }^{12}$ in conjunction with the recognition of Germany's immunity. With Judgment No. 238 of 2014, the Corte Costituzionale affirmed that the recognition of the immunity of foreign States from civil jurisdiction in Ferrini-like circumstances (i.e. when it precludes judicial examination and compensation for damages for gross violations of human rights suffered by victims of war crimes and crimes against humanity) violates Articles 2 and 24 of the Constitution. It thus declared the domestic rules requiring the courts to comply with the 2012 ICJ Judgment, i.e. Article 3 of Law No. 5 of 2013 and Article 1 of Law No. 848 of 1957, to be unconstitutional, and stated that, in these circumstances, the relevant customary international norm did not "enter" the Italian legal system at all by means of Article 10(1) of the Constitution. According to the Court, when contrary to a fundamental constitutional principle, a customary international rule-having "a rank equivalent to constitutional by virtue of the reference made by Article

Germany, 21 February 2013, No. 4284. Several other Italian judicial decisions going along the same lines are reported in FOCARELLI, Trattato, cit. supra note 5, pp. 2132-2135.

"The Italian legal system conforms to the generally recognised principles of international law" ("Lordinamento giuridico italiano si conforma alle norme del diritto internazionale generalmente riconosciute").

11 "The Republic recognises and guarantees the inviolable rights of the person, both as an individual and in the social groups where human personality is expressed. [...]" ("La Repubblica riconosce e garantisce i diritti inviolabili dell'uomo, sia come singolo, sia nelle formazioni sociali ove si svolge la sua personalità. [...]").

12 "Anyone may bring cases before a court of law in order to protect their rights under civil and administrative law. [...]" ("Tutti possono agire in giudizio per la tutela dei propri diritti e interessi legittimi. $[\ldots] ")$. 
10(1) of the Constitution"- "does not enter the Italian legal system and cannot, therefore, be applied", that is, it "does not [...] produce [...] any effect" in the Italian system since, in such a case, "the reference made by Article 10(1) of the Constitution [to general international law] does not operate". ${ }^{13}$ The Court reached this conclusion on the basis of the doctrine of "counter-limits", which refers to the "limits" to the application of international law in the Italian legal system. ${ }^{14}$

While this is certainly the key finding of Judgment No. 238 , a few other passages deserve consideration for the purposes of the present analysis.

To reach its conclusions, the Court had firstly to determine whether it had competence to review the general international rule on State immunity and its operation within the Italian legal system by virtue of Article 10(1) of the Constitution. On this point, the Court affirmed its competence, and pointed out that it was exclusive. In other words, according to the Court, it is only for the Corte Costituzionale (that is, excluding all other Italian courts) to review the constitutionality of general international law in the Italian legal system. This statement apparently goes against Article 134 of the Italian Constitution whereby, in particular, the Corte Costituzionale "shall pass judgement" on "controversies on the constitutional legitimacy of laws and enactments having force of law issued by the State and Regions". In other words, Article 134 does not expressly entrust the Corte Costituzionale with the power to review general international law, since this clearly does not amount to "laws and enactments having force of law issued by the State and Regions". The Court concluded in favour of its exclusive competence by noting that "the norm subject to the referral made by Article 10(1) of the Constitution to customary international law, cannot be excluded from constitutional review only because Article 134

13 Corte Costituzionale, Simoncioni and others v. Germany and President of the Council of Ministers, 22 October 2014, No. 238, paras. 3.4-3.5.

14 Favouring the idea that Art. $10(1)$ of the Constitution, "if systematically interpreted, contains an implicit clause safeguarding the fundamental values (and only those who are so) which inspire our Constitution" and "it cannot, nor purports to give effect to customary international law within the domestic legal system to the extent of a rupture with those values", so that "a general international rule crossing that limit cannot be considered to fall under the scope of Art. 10 and will remain inoperative within the State" with the consequence that "all those who are called upon to apply it, first and foremost the judges, will be able to refuse doing so without a pronouncement of the Corte Costituzionale being necessary on the issue", see Conforti, Diritto internazionale, 1oth ed., Napoli, 2014, p. 348 (author's translation); ID., "La Corte costituzionale e i diritti umani misconosciuti sul piano internazionale", Giurisprudenza costituzionale, 2014, p. 3885 ff. In Judgement No. 238, the Corte Costituzionale seems to have adopted this argument's premise, but not its consequences. 
of the Constitution does not explicitly envisage this specific possibility". In the Court's view, under Article 134, "all laws, acts and norms that have the same legal effects as formal laws (ordinary or constitutional), but came into being through means other than the legislative process-including the aforementioned [customary international] norms - are subject to centralized constitutional review" and "there is no reason, from a logical and systematic standpoint, to exclude the constitutional review of international customs" (para. 2.1). The Court also found that there was no reason to limit the operation of Article 134 "to [international] customs subsequent to the Constitution". With this statement, the Court apparently repudiated its own 1979 Russel Judgment, according to which all international customs that were formed before the entry into force of the Italian Constitution (1 January 1948) do override, by virtue of Article 10(1) of the Constitution, any constitutional norm, including fundamental constitutional principles. ${ }^{15}$ The Court, in fact, implied that customary international law (while overriding ordinary constitutional rules) never overrides fundamental constitutional principles, regardless of whether it emerged before (as in the case of the State immunity rule) or after the entry into force of the Italian Constitution. Based on this premise, the Court found that Articles 2 and 24 of the Constitution could not be overruled by the customary international rule on State immunity, notwithstanding the fact that the latter emerged before 1948.

15 Corte Costituzionale, Russell v. Immobiliare Soblim Srl, 18 June 1979, No. 48, para. 3. In the Russel Judgment the Court held in particular that customary international rules that pre-exist the Constitution, such as those on diplomatic immunities, prevail over any constitutional law rule (including "fundamental" rules) on the basis of the speciality principle. Instead, customary international rules that are subsequent to the date of entry into force of the Constitution, prevail over constitutional rules except for the "fundamental principles" of the Italian constitutional order as identified by the Corte Costituzionale itself in its jurisprudence. The Russel Judgment was reaffirmed by the Corte di Cassazione in a number of cases (Corte di Cassazione (Sezioni Unite Civili), Presidency of the Council of Ministers v. Italian Federation of Transport Workers of Trento Province and others, 3 August 2000, No. 530; Corte di Cassazione (Sez. I penale), Criminal proceedings against Mario Luiz Lozano, 24 July 2008, No. 31171; Corte di Cassazione (Sezioni Unite Civili), United States v. Tissino and others, 25 February 20o9, No. 4461 (Order). However, the Corte Costituzionale, especially in the 1996 Pahor and 2001 Baraldini Judgments (Concessionario della Provincia di Trieste v. Pahor Samo and others, 29 January 1996, No. 15; Baraldini, 22 March 2001, No. 73, para. 3.1), failed to recall this temporal criterion and it only asserted, specifically in Baraldini, that the "supreme principles of the constitutional order of the State" and the "inalienable rights of the person" constitute a "limit to the entrance" of general international law under Italian law, by means of Article 10(1) of the Constitution (see infra note 31). In the 2009 Milde Judgment, the Corte di Cassazione seems to have followed this stance (Corte di Cassazione (Sez I penale), Criminal proceedings against Max Josef Milde, 21 October 2008, No. 1072, para. 7). 
With regard to Article 24 of the Constitution, the Court pointed out that the right of access to court, as a "fundamental" constitutional principle-as such, overriding customary international law-may yield to "a public interest recognizable as potentially prominent". More specifically, according to the Court, "this limit has to be justified by reasons of public interest potentially prevailing over the principle of Article 24 Constitution", and "the provision that establishes the limit has to guarantee a rigorous assessment of the [public] interest in light of the concrete case". In the instant case, in the Court's view, "the customary international norm of immunity of foreign States, defined in its scope by the ICJ, entailed the absolute sacrifice of the right to judicial protection, insofar as it denied the jurisdiction of [domestic] courts to adjudicate the action for damages put forward by victims of crimes against humanity and gross violations of fundamental human rights", and "[t]his in itself rules out $[\ldots]$ acts such as deportation, slave labor, and massacres, recognized to be crimes against humanity", since "[ $\mathrm{t}]$ he immunity of the foreign State from the jurisdiction of the Italian judge granted by Articles 2 and 24 Constitution protects the [sovereign] function [of State]", and "does not protect behaviors that do not represent the typical exercise of governmental powers, but are explicitly considered and qualified unlawful, since they are in breach of inviolable rights". In brief, according to the Court, "in an institutional context characterized by the centrality of human rights $[. .$.$] the denial of judicial protection of$ fundamental rights of the victims of the crimes at issue now (dating back in time), determines the completely disproportionate sacrifice of two supreme principles of the Constitution" (para. 3.4).

Judgment No. 238 has immediately received extensive comments, both of approval and disapproval. ${ }^{16}$ Legal scholars who, in the past, had supported

16 MELONI, "La Corte costituzionale annulla gli effetti della decisione della CIG in materia di immunità giurisdizionale dello Stato estero", Diritto penale e uomo, 24 October 2014; TAMs, "Let the Games Continue: Immunity for War Crimes before the Italian Constitutional Court", EJIL Talk!, 24 October 2014, available at: <https://www.ejiltalk.org/let-the-games-continueimmunity-for-war-crimes-before-the-italian-supreme-court/>; FORLATI, "The Italian Constitutional Court Rules on Immunity of Foreign States From Civil Jurisdiction: A New Twist in the Ferrini Saga", Aldricus, 27 October 2014; G RADONI, "Corte Costituzionale italiana e Corte internazionale di giustizia in rotta di collisione sull'immunità dello Stato straniero dalla giurisdizione civile", SIDIBlog, 27 October 2014, available at: <http://www.sidiblog. org/2014/10/27/corte-costituzionale-italiana-e-corte-internazionale-di-giustizia-in-rotta-dicollisione-sullimmunita-dello-stato-straniero-dalla-giurisdizione-civile/>; FONTANELLI, “I know It's Wrong but I Just Can't Do Right: First Impressions on Judgment No. 238 of 2014 of the Italian Constitutional Court", Verfassungsblog, 27 October 2014, available at: $<$ https://verfassungsblog.de/know-wrong-just-cant-right-first-impressions-judgment-2382014-italian-constitutional-court/>; DE SENA, "Spunti di riflessione sulla sentenza 238/2014 della Corte costituzionale", SIDIBlog, 30 October 2014, available at: <http://www.sidiblog. org/2014/10/3o/spunti-di-riflessione-sulla-sentenza-2382014-della-corte-costituzionale/>; 
the "humanitarian exception" to immunity in international law, have tended to favour the "payback" operated by the Corte Costituzionale, thinking of it almost as a victory of international law, although international law is neither made nor unmade by individual States. Critically, it has been argued that Judgment No. 238 is a dangerous act of disobedience against the ICJ, which creates a breach in international law threatening the principle of good faith in

Fontanelli, "The Italian Constitutional Court's Challenge to the Implementation of the ICJ's Germany v Italy Judgment", iLawyer, 30 October 2014, available at: <https:// ilawyerblog.com/italian-constitutional-courts-challenge-implementation-icjs-germanyv-italy-judgment/>; FARAGUnA, "Corte costituzionale contro Corte internazionale di giustizia”, Forum di Quaderni costituzionali, 2 November 2014, available at: <https:// www.forumcostituzionale.it/wordpress/wp-content/uploads/2013/o5/QC_2014_238.pdf>; GUAzZARотTI, "Il paradosso della ricognizione delle consuetudini internazionali. Note minime a Corte cost. n. 238 del 2014", Forum di Quaderni costituzionali, 5 November 2014, available at: <https://www.forumcostituzionale.it/wordpress/wp-content/uploads/2014/11/ guazzarotti_nota_238_2014.pdf>; LIETO, "Il diritto al giudice e l'immunità giurisdizionale degli Stati nella sentenza della Corte costituzionale n. 238 del 2014", Forum di Quaderni costituzionali, 6 November 2014, available at: <https://www.forumcostituzionale.it/ wordpress/wp-content/uploads/2014/11/lieto_nota_238_2014.pdf>; GRADONI, “Giudizi costituzionali del quinto tipo. Ancora sulla storica sentenza della Corte costituzionale italiana", SIDIBlog, 10 November 2014, available at: < http://www.sidiblog.org/2014/11/10/ giudizi-costituzionali-del-quinto-tipo-ancora-sulla-storica-sentenza-della-cortecostituzionale-italiana/>; LONGOBARDO, "Il non-essere non è e non può essere': brevi note a margine della sentenza n. 238/2014 della Corte costituzionale rispetto all'adattamento dell'ordinamento italiano al diritto internazionale consuetudinario", SIDIBlog, 10 November 2014, available at: <http://www.sidiblog.org/2014/11/10/il-non-essere-non-e-e-non-puoessere-brevi-note-a-margine-della-sentenza-n-2382014-della-corte-costituzionale-rispettoalladattamento-dellordinamento-italiano-al/>; schilling, "The Dust Has Not Yet Settled: The Italian Constitutional Court Disagrees with the International Court of Justice, Sort of", EJIL Talk!, 12 November 2014, available at: <https://www.ejiltalk.org/the-dust-hasnot-yet-settled-the-italian-constitutional-court-disagrees-with-the-international-courtof-justice-sort-of/>; LEONE, "Sul dispositivo della sentenza n. 238 del 2014: una soluzione preordinata ad accentrare il sindacato sulle consuetudini internazionali presso Palazzo della Consulta", Forum di Quaderni costituzionali, 13 November 2014, available at: <https://www. forumcostituzionale.it/wordpress/wp-content/uploads/2014/11/238-2014-nota-leone.pdf >; DE SENA, "Norme internazionali generali e principi costituzionali fondamentali, fra giudice costituzionale e giudice comune (ancora sulla sentenza 238/2014)", SIDIBlog, 17 November 2014, available at: <http://www.sidiblog.org/2014/11/17/norme-internazionali-generalie-principi-costituzionali-fondamentali-fra-giudice-costituzionale-e-giudice-comuneancora-sulla-sentenza-2382014/>; GRADONI, "Corte costituzionale italiana 'controvento' sull'immunità giurisdizionale degli Stati stranieri?", Forum di Quaderni costituzionali, 17 November 2014, available at: <https:/www.forumcostituzionale.it/wordpress/wp-content/ uploads/2014/11/238-2014-nota-gradoni.pdf>; RONZITTI, "Crimini di guerra e risarcimenti", Affari internazionali, 18 November 2014, available at: <https://www.affarinternazionali. it/2014/11/crimini-di-guerra-e-risarcimenti/>; PIN, “Tearing Down Sovereign Immunity's Fence-The Italian Constitutional Court, the International Court of Justice, and the German War Crimes", Opinio juris, 19 November 2014, available at: <http://opiniojuris.org/2014/11/19/ 
inter-State relations and the stability of the international legal system ensured by the immunity rule. From this perspective, the Judgment appeared to reinforce unilateralism, even though under the guise of humanitarianism, and it contributed to emphasising the "soft" or "flexible" (that is, ultimately political) character of international law, which is typically invoked by stronger States.

As a result, legal proceedings before many Italian courts (including the Corte di Cassazione) have been resumed, currently, thus, in overt violation of international law and the ICJ decision.

Judgment No. 238 has been followed in a good number of cases, also involving States other than Germany, including by the Tribunale di Firenze in its 2015 Alessi and Bellini Order No. 1300/2012 and 2016 Bergamini and Simoncioni Judgments; the Tribunale di Piacenza, in the 2015 Rabizzoni and Carini Judgment; the Corte di Cassazione, in the 2015 Flatow and Opacic Judgments, and in the 2016 Gamba Judgment; the Tribunale di Roma, in the 2016 Cavallina Judgment; the Tribunale di Sulmona, in its 2017 Comune di Roccaraso Judgment, and so on. ${ }^{17}$

guest-post-tearing-sovereign-immunitys-fence-italian-constitutional-court-internationalcourt-justice-german-war-crimes/>; Castellaneta, "La Consulta apre la strada ai risarcimenti", Il Sole 24 Ore-Guida al diritto, 22 November 2014; TANZI, "Sulla sentenza Cost. 238/2014: cui prodest?" Forum di Quaderni costituzionali, 26 November 2014, available at: <https:// www.forumcostituzionale.it/wordpress/wp-content/uploads/2014/12/nota_238_2014_tanzi. pdf>; GRADONI, "Un giudizio mostruoso. Quarta istantanea della sentenza 238/2014 della Corte costituzionale italiana", SIDIBlog, 15 December 2014, available at: <http://www. sidiblog.org/2014/12/15/un-giudizio-mostruoso-quarta-istantanea-della-sentenza-2382014della-corte-costituzionale-italiana-2/>. Before Judgment No. 238 the issue had been largely analysed, see for example D'AGNONE, "Immunità degli Stati stranieri e garanzia costituzionale dell'accesso al giudice: conflitto reale?", Quaderni costituzionali, 2014, pp. 639 ff.; CATALDI, “The Implementation of the ICJ's Decision in the Jurisdictional Immunities of the State Case in the Italian Domestic Order: What Balance Should be Made between Fundamental Human Rights and International Obligations?", ESIL Reflections, 24 January 2013, available at: <https://esil-sedi.eu/post_name-628/>; PALOMBIno, "Italy's Compliance with ICJ Decisions vs. Constitutional Guarantees: Does the 'Counter-Limits' Doctrine Matter?", Italian Yearbook of International Law, 2012, pp. 185 ff.; RUsso, "Il rapporto tra norme internazionali generali e principi della Costituzione al vaglio della Corte costituzionale: il Tribunale di Firenze rinvia alla Consulta la questione delle vittime dei crimini nazisti", Osservatorio sulle fonti, 2014, available at: <https://www.osservatoriosullefonti.it/ mobile-note-e-commenti/note-e-commenti-n-1-2014/69o-osf-1-2014-russo >.

17 Tribunale di Firenze, Alessi and Bellini v. Federal Republic of Germany and Presidency of the Council of Ministers, 23 March 2015, No. 1300/2012 (Order); Tribunale di Firenze, Bergamini v. Federal Republic of Germany and Presidency of the Council of Ministers, 6 July 2015, 
These decisions have often given questionable reasons for their conclusions. For example, in the 2016 Gamba Judgment, the Corte di Cassazione held that "once Article 3 of Law No. 5 of 2013 has been voided, together with the obligation of the Italian courts to conform to the ICJ decision of 3 February 2012, no other conclusion is possible than affirming the jurisdiction of the Italian courts to decide the claims for damage advanced by the plaintiffs". This seems a rather curious stance, to say the least, when considering that, as hinted earlier, ${ }^{18}$ the same Corte di Cassazione (together with several other Italian courts) had previously immediately aligned with the ICJ decision and it had failed to raise the issue of constitutionality regarding the ICJ decision before Article 3 of Law No. 5 of 2013 was adopted, although it might well do so. Interestingly, the Tribunale di Firenze raised the question of constitutionality of the ICJ Judgment and of Article 3 of Law No. 5 of 2013 (later to be decided by the Corte Costituzionale with Judgment No. 238) on 21 January 2014, i.e. the very same day that the Corte di Cassazione (Joint Chambers (Sezioni Unite), "ss.uu.") deposited the F.R., F.G. (Ferrini) Judgment No. 1136/14, stating that "no doubt of constitutionality may be adumbrated with regard to the provisions of Article 3 of [Law No. 5 of 2013,] given that they are dictated for the purposes of Article 94(1) of the UN Charter" in application of Article 11 of the Constitution (second sentence). ${ }^{19}$

More recently, in the Toldo Judgment No. 20442 of 2020, the Corte di Cassazione (ss.uu.) repealed the Judgment of the Corte d'appello di Firenze, and affirmed instead Judgment No. 238 of 2014 of the Corte Costituzionale. This case nicely illustrates the oscillating attitude of the Italian jurisprudence on the issue. In the first instance, the Tribunale di Firenze had recognized (with a Judgment of 14 March 2012) the immunity of Germany, on the grounds that the newly issued ICJ Judgment was immediately and directly operative within the Italian legal system. However, in 2014 the same Tribunale, dealing with another Ferrini-like case, raised the question of constitutionality that led to

No. 14049/2011; Tribunale di Firenze, Simoncioniv. Federal Republic of Germany and Presidency of the Council of Ministers, 6 July 2015, No. 8879/2011; Tribunale di Piacenza, Rabizzoni and Carini, 25 September 2015, No. 723/2015; Corte di Cassazione (Sezioni Unite Civili), Francine Flatow and others v. Islamic Republic of Iran and others, 28 October 2015, No. 21946; Corte di Cassazione (Sez. I penale), Criminal proceedings against Opacic Dobrivoje, 29 October 2015, No. 43696; Corte di Cassazione (Sezioni Unite Civili), Gamba and others v. Federal Republic of Germany and Presidency of the Council of Ministers, 29 July 2016, No. 15812; Tribunale di Roma, Cavallina, 10 October 2016; Tribunale di Sulmona, Comune di Roccaraso and others v. Federal Republic of Germany, 2 November 2017. All these decisions are reported in FOCARELLI, Diritto internazionale - II Prassi (2012-2019), Milano, 2019.

18 See supra note 8.

19 Corte di Cassazione (Sezioni Unite Civili), Federal Republic of Germany v. F.R. and F.G., 21 January 2014, No. 1136, available at: <https:/www.questionegiustizia.it/data/doc/334/ cassazione_germania_1136-14.pdf >. 
Judgment No. 238 of the Corte Costituzionale. Afterwards, the Corte d'appello di Firenze affirmed (with Judgment No. 2945 of 2018) the 2012 Judgment of the Tribunale, without following (and hence, without assuming that it was compelled to follow) Judgment No. 238, noting that the same Corte di Cassazione had "disavowed" (sconfessato) its own stance with the above-mentioned Ferrini Decision No. 1136 of 2014. ${ }^{20}$ Finally, with Judgment No. 20442 of 2020, the Corte di Cassazione (ss.uU.) "disavowed its disavowal", and denied the immunity to Germany, on the grounds that it was compelled to align with Judgment No. 238. In this decision, the Corte di Cassazione has conceded that it "had changed its [pro-Ferrini] attitude" being compelled to do so by the lawmaker through Article 3 of Law No. 5 of 2013 (para. 1.3), omitting, however, that it had already spontaneously conformed to the ICJ Judgment before the issuance of Article 3 of Law No. 5 of $2013 .{ }^{21}$ The Court went on stating that this change of attitude, allegedly forced upon it by the lawmaker, "cannot be questioned anymore" in light of Judgment No. 238 (para. 1.4), which is considered to be an "interpretative judgment of rejection", and as such binding "on the court" (para. 1.5). Nonetheless, according to some commentators, the binding effect of Judgement No. 238 is limited to the referring court. The Corte di Cassazione has concluded that the approach taken by the Corte d'appello "is, by now, surpassed", without the slightest consideration for the internationally unlawful act that Italy is nonetheless committing, which is anything but surpassed. ${ }^{22}$

Since various legal proceedings have been resumed after Judgment No. 238, with some of them eventually ordering Germany to compensate the applicants (and Germany being unwilling to do so), analogous uncertainties have arisen with regard to the immunity of Germany from measures of constraint. In the 2018 Regione Sterea Ellada Judgment, the Italian Corte di Cassazione (Section III) accorded Germany immunity from measures of constraint against Villa Vigoni, a cultural German building located in Italy on which a judicial mortgage had been imposed, stating that under Article 10 of the Italian Constitution "Italian courts have no jurisdiction in respect of a request for measures of constraint against property belonging to foreign States or sub-State public entities, where such property is intended for use in the performance of sovereign, or in any event, public functions". The Court also affirmed that the finding of a

\footnotetext{
20 See supra note 18.

$21 \quad$ See supra note 8.

22 For a comment, see venturini, "Sezioni Unite, sentenza n. 20442 del 2020: il 'contrappunto fugato' della sent. 238/2014 Corte cost., SIDIBlog, 18 December 2020, available at: <http:// www.sidiblog.org/2020/12/18/sezioni-unite-sentenza-n-20442-del-202O-il-contrappuntofugato-della-sent-238-2014-corte-cost/>, holding that Judgment No. 238 is binding only on the referring court.
} 
lower court that Villa Vigoni is indeed property intended for use in the performance of governmental functions is "reasonable", but this does not prevent measures of constraint on German property located in Italy that may be characterized as not intended for use in the performance of governmental functions. As a result, the enforceable title that was relevant in the instant case remained valid in itself, although it could not be applied to Villa Vigoni. On this point, the Court ordered the removal of the judicial mortgage. ${ }^{23}$ Interestingly, this decision has mentioned Judgment No. 238 - concerning the different, but closely connected, rule on immunity from jurisdiction—but it has taken for granted that the "customary international rule" on immunity of foreign States from measures of constraint against property that is intended for use in the performance of governmental functions, applies and fully operates within the domestic legal system by virtue of Article 10 of the Constitution, without raising any issue in relation to the possible overriding effects of either international jus cogens, or of Articles 2 and 24 of the Constitution on such customary rule. It has, thus, apparently accepted that not only does the immunity rule apply internationally, but it also straightforwardly "enters" the Italian legal system, regardless of any possible constitutional "counter-limit".

However, in the Deutsche Bahn AG v. Regione Sterea Ellada and Federal Republic of Germany, Rete Ferroviaria Italiana Spa, Trenitalia Spa Judgment No. 21995 of 3 September $2019,{ }^{24}$ the Italian Corte di Cassazione (the same Section III of the Regione Sterea Ellada 2018 decision, but this time with totally different members) took a different stance. According to the Court, "the judgment of the ICJ is not directly binding [...] on individuals or organs, including judicial ones [...], as proved by the fact that [for that very purpose] a reception law was necessary" (para. 14). In any event, "even the domestic rule of reception [...] could not have direct effect on the constraint proceedings" (para. 17); "the immunity of foreign States from civil jurisdiction for acts jure imperii amounts to a prerogative (and not a right)" (para. 22); and the "Italian courts, both those engaged in jurisdiction proceedings and those engaged in execution proceedings [...] have the institutional duty, by reason of the unquestionable respect due to Judgment No. 238 of 2014 of the Corte Costituzionale, to deny any exemption from that jurisdiction [...] both in jurisdictional proceedings or proceedings of recognition of a foreign judgment and [...] in execution proceedings"

23 Corte di Cassazione (Sez. III civile), Regione Sterea Ellada v. Presidency of the Council of Ministers and Federal Republic of Germany, 8 June 2018, No. 14885, paras. 14, 24-25.

24 Corte di Cassazione (Sez. III civile), Deutsche Bahn AG v. Regione Sterea Ellada and Federal Republic of Germany, Rete Ferroviaria Italiana Spa, Trenitalia Spa, 3 September 2019, No. 21995 . 
(para. 23). This Judgment raises a number of doubts. Firstly, it ignores (or pretends to ignore) that the ICJ decision had been immediately applied by Italian courts, including the Corte di Cassazione itself (ss.uU.) before the issuance of a domestic law of reception of that Judgment. Secondly, it reduces the right to immunity to a "prerogative" (as opposed to a "right"), thus exhuming old, "diplomatic" or "political", opportunistic conceptions of international law. Finally, after totally devaluing both the ICJ decision and the international rule on State immunity, it avoids explaining the reasons why Judgment No. 238 applies also to execution proceedings, as well as the reasons why the Court has changed its mind in relation to the 2018 Regione Sterea Ellada decision, which the same Section III had delivered just a year before. Also, this decision was taken with total indifference for the continuation of Italy's international unlawful conduct, and for the support the decision may provide to it. ${ }^{25}$

Seven years since its adoption, a number of shortcomings of Judgment No. 238 remain valid. Let us have a summary look at them.

Firstly, while referring in the abstract to the perspective of "achieving the goal of maintaining good international relations, inspired by the principles of peace and justice, for whose realization Italy agrees to limitations of sovereignty by virtue of Article 11 of the Constitution" (para. 3.4), Judgment No. 238 completely failed to consider the global system wherein Italy exists, which guarantees also the country's national security. This may well represent, in the Court's words, "a public interest recognizable as potentially prominent", possibly prevailing on Articles 2 and 24 of the Constitution. Similarly, the ruling disregarded the actual or intended legal bearing that, as a precedent, it has on the stability of the global system, a factor that the US Supreme Court, for example, took very seriously, when deciding on an equally sensitive area of international law (unsurprisingly cited in the 2021 Philipp Judgment on State immunity) in the 2013 Kiobel and 2018 Jesner Judgments, concerning the application of the Alien Tort Claims Act ("ATCA"), also known as the Alien Tort Statute ("ATs"), to multinational corporations operating abroad. ${ }^{26}$ Such overall implications

25 For a comment pulling in the opposite direction, see BERRINO, "La Corte di cassazione torna sul tema delle immunità giurisdizionali degli Stati e dei loro beni”, RDI, 2020, p. $844 \mathrm{ff}$.

26 Supreme Court (United States), Kiobel v. Royal Dutch Petroleum Co., cit. supra note 2, p. 13 ('accepting petitioners' view would imply that other nations, also applying the law 
are best illustrated in a decision of 19 April 2016 of the Russian Constitutional Court, holding, by "freshly exercising" a power to "settle the issue of the possibility of executing a decision by an interstate body for the defense of human rights and freedoms", conferred on it by a law which entered into force in Russia on 14 December 2015, that the 2013 Anchugov and Gladkov Judgment of the European Court of Human Rights ("ECtHR") — whereby Russia's blanket ban on convicted prisoners' voting rights violated the European Convention on Human Rights ("ECHR") — was "impossible to implement" because of its implied incompatibility with Article $32(3)$ of the Russian Constitution. ${ }^{27}$ Least of all did Judgement No. 238 account for the possibility that the principle it has affirmed could be inversely applied, were Italy to be required to compensate an indefinite number of victims and their heirs, a perfectly plausible case in practice, since Italy too did notoriously committed serious human rights violations, including, but not exclusively, before and during Second World War (such as in Libya, Ethiopia, the Balkans and Greece). ${ }^{28}$

Secondly, Judgment No. 238 has mentioned a parallelism with the jure gestionis exception to the immunity rule, assuming that, in a like manner, it would

of nations, could hale our citizens into their courts for alleged violations of the law of nations occurring in the United States, or anywhere else in the world. The presumption against extraterritoriality guards against our courts triggering such serious foreign policy consequences, and instead defers such decisions, quite appropriately, to the political branches"); Supreme Court (United States), Jesner et al. v. Arab Bank, Plc, Judgement of 24 April 2018, p. 24, available at: <https://www.supremecourt.gov/opinions/17pdf/16-499_1a7d. pdf $>$. In 2013, the Supreme Court had ruled in the Kiobel Judgment that the ATCA does not extend to suits against foreign corporations when "all the relevant conduct took place outside the United States", but it did not resolve the broader question about whether foreign corporations (in addition to natural persons) may be sued under the ATCA at all. In Jesner, the Supreme Court noted that, before recognizing an ATCA common-law action, federal courts must apply a two-part test announced in its previous jurisprudence, that is, "whether a plaintiff can demonstrate that the alleged violation is 'of a norm that is specific, universal, and obligatory' and 'whether allowing the case to proceed under the ATs [Alien Tort Statute] is a proper exercise of judicial discretion or whether caution requires the political branches to grant specific authority before corporate liability can be imposed"'. The Court concluded that in the instant case a foreign corporation could not be sued under the ATCA.

27 Russian Constitutional Court, The Case Concerning the Resolution of the Question of the Possibility to Execute in Accordance with the Constitution of the Russian Federation the Judgment of the European Court of Human Rights of 4 July 2013 in the Case of Anchugov and Gladkov v. Russia in Connection with the Request of the Ministry of Justice of the Russian Federation, Judgment of 19 April 2016, English translation available at: <http://www.ksrf.ru/ en/Decision/Judgments/Documents/2016_April_19_12-P.pdf>; ECtHR, Anchugov \& Gladkov v. Russian Federation, Applications No. $11157 / 04$ and 15162/05, Judgment of 12 September 2013.

28 See DEL воCA, Italiani, brava gente?, Vicenza, 2005. 
be possible to deviate again from existing general international law for reasons of justice, just like Italian courts are deemed to have done in the second half of the 19th century and at the beginning of the 2oth century. Nonetheless, the Court has not considered that the Italian rulings in favour of the jure gestionis exception were also grounded on the idea that the rule of absolute immunity did not reflect at the time general international law, and thus could be eschewed without departing from it, much less violating it. There are cases in which the Italian courts held that the "restricted theory" was anything but "new", since immunity had been always denied in respect of acts jure gestionis and by assuming that the "absolute" immunity rule never existed, a view that, significantly, has been recently defended by the UK Supreme Court in the 2017 Benkharbouche Judgment. ${ }^{29}$ From this perspective, there is no parallelism that could justify a sort of repetition of the same process today, with regard to the so-called "humanitarian exception" to immunity. Furthermore, Judgement No. 238 has not considered that, as far as the "evolution" of the rule on immunity is concerned, the two exceptions differ greatly and have very different chances to take hold, if nothing else because almost every State has committed in the past some acts that, today, would amount to serious human rights violations. It is highly unlikely, in other words, that States will be willing to accept the Court's principle (at least without qualifications, such as its application only to present and future violations) and, in any case, the likelihood of such acceptance has to be reasoned, something that the Court did not do.

Thirdly, and a closely related consideration, in Judgment No. 238 the Court hinted at its willingness to contribute to the transformation of existing international law in the name of the fundamental values set out in the Italian Constitution. In its view, "the result" of its Judgment "is a further reduction of the scope of [the immunity] rule [in addition to that which, to its mind, marked, in the past, the development from absolute to relative immunity], with

29 See, for example, Corte d'Appello di Genova, Governo Francese v. Serra and C. v. Ceretti and others, 4 May 1925, RDI, 1925, p. 540 ff., p. 543, holding that "disagreement among the judicial authorities of different countries simply demonstrates that the different States hold different opinions and legal beliefs [on whether denying State immunity for jure gestionis acts amounts or not to a violation of international law] and that an international rule [in favour of absolute immunity] that is generally recognized as legally binding is still lacking" (author's translation). In the Benkharbouche Judgement the UK Supreme Court has affirmed, upon a thorough analysis of relevant practice, that "there has probably never been a sufficient international consensus in favour of the absolute doctrine of immunity to warrant treating it as a rule of customary international law", see Supreme Court (United Kingdom), Benkharbouche v. Secretary of State for Foreign and Commonwealth Affairs and Secretary of State for Foreign and Commonwealth Affairs v. Janah, Judgment of 18 October 2017, para. 52, available at: <https://www.supremecourt.uk/cases/docs/uksc-2015-oo63-judgment.pdf>. 
effects in the domestic legal order only", but "[a]t the same time [...] this may also contribute to a desirable - and desired by many — evolution of international law itself" (para. 3.3, emphasis added). However, the Court completely ignored the overall environment in which the Judgment is supposed to "contribute to a desirable [...] evolution of international law itself". Moreover, while undoubtedly the Ferrini jurisprudence is best explained from this dynamic perspective (a point further expounded below), the stance taken by Judgment No. 238 lends itself to the criticism of being poorly reasoned, just like in the above-mentioned case of the Corte di Cassazione, since the Corte Costituzionale developed no argument to make its case credible and potentially acceptable to the courts of other States. In particular, the judgement has not attempted to clarify why or to what extent other States and their courts should follow its example, so as to achieve an "evolution" of customary international law of the kind advocated by the Court. ${ }^{30}$ Such clarification would have required a detailed analysis of the functioning of the international system and of its equilibriums, so as to devise a tailored rule that would be realistically acceptable to others and would constructively contribute to the desired evolution of international law, while at the same time being in line with the Italian Constitution.

Fourthly, Judgement No. 238 has not taken into account, not even cursorily or critically, the fact that the Italian Legal Counsel of State (Avvocatura dello Stato) and the Italian Government - that is, any Italian government, irrespective of its political colour, and apart from the (unsuccessful) parenthesis before the ICJ—-stands firmly in support of Germany's position in terms of existing international law. ${ }^{31}$ In fact, the Italian Avvocatura dello Stato, led by the Attorney General, pleaded that the immunity rule be applied in the course of the Mantelli and all other ongoing proceedings before Italian courts, stating that the Ferrini decision "is a unicum in the panorama of domestic and international jurisprudence", that is not "in line with the current status of international law", and that it "constitute[ed] a case completely incapable of creating a rule of international law". ${ }^{2}$ Judgement No. 238 has been indifferent to the

30 On the contrary, the Judgement has apparently undermined the credibility of Italy's compliance with international law. In this sense, see for instance India's statements before the ITLOS in relation to the Enrica Lexie case, according to which, following Judgement No. 238 , there were no guarantees anymore that Italy would have respected an arbitral decision in favour of India's jurisdiction, ITLOS/PV.15/C24/2, p. 39 ff., and ITLOS/PV.15/C24/4, pp. 13 and $15-16$. On the point, see also the reply of the ad hoc Judge Francioni (who had been chosen by Italy), paras. 10 and 15 .

$31 \quad$ On this issue, see scovazzI, “Come se non esistesse", RDI, 2021, p. $167 \mathrm{ff}$.

$3^{2}$ The statement, submitted at the hearing of 6 May 2008, is not mentioned in the Mantelli and other Orders (Nos 14200 to 14212) of 2008 (Corte di Cassazione (Sezioni Unite Civili), 
reasons behind this fact, although these could have, rather, led the Court to a more balanced and realistic reading of the Constitution, a reading that would have had greater chances (of evident concern for the Government) to be followed by other States, thus effecting the "evolution" of the regime on immunities in the direction encouraged by the Court itself.

Fifthly, Judgement No. 238 pretended not to be concerned with nor, even less, willing to assess or "review" the above-mentioned ruling of the ICJ, stating that "[ $t]$ he Court, indeed, cannot exercise such a control", since "[i]nternational custom is external to the Italian legal order, and its application [...] must respect the principle of conformity, i.e. must follow the interpretation given in its original legal order, that is the international legal order" (para. 3.1). However, it has actually reviewed the ICJ decision, although for domestic constitutional purposes, and it has endorsed certain stances that are methodologically in overt contrast with said ruling. For instance: (a) the inference of a procedural right of access to court from fundamental substantive rights, given that "[w]ith an eye to the effectiveness of judicial protection of fundamental rights [...] the recognition of rights goes hand in hand with the recognition of the power to invoke them before a judge in judicial proceedings" (para. 3.4), is at odds with para. 93 of the ICJ decision, whereby " $[t]$ he rules of State immunity are procedural in character and are confined to determining whether or not the courts of one State may exercise jurisdiction in respect of another State", and "[t]hey do not bear upon the question whether or not the conduct in respect of which the proceedings are brought was lawful or unlawful"; (b) the notion that an international crime cannot be an act jure imperii of a State that is covered by the immunity rule, when ruling out that "acts such as deportation, slave labor, and massacres, recognized to be crimes against humanity, can justify the absolute sacrifice in the domestic legal order of the judicial protection of inviolable rights of the victims of those crimes" (para. 3.4) is at odds with para. 60 of the ICJ Judgment, whereby "[ $\mathrm{t}]$ he acts of the German armed forces and other State organs which were the subject of the proceedings in the Italian courts clearly constituted acta jure imperii" which are covered, in principle, by the immunity rule, despite being unlawful; (c) the exclusion of "the application of the [2004 UN Convention on the immunity of States and their property] and its

Federal Republic of Germany v. Giovanni Mantelli and others, 29 May 2008, No. 14201 (Order). It is unpublished, but lodged with the Italian Ministry of Foreign Affairs). A critical stance against Ferrini was also publicly taken by the Italian Minister of Foreign Affairs in an interview released to the Swiss newspaper Süddeutsche Zeitung, published on 20 June 2008, where the Minister termed the Ferrini jurisprudence "dangerous", and confirmed that Italy had an interest in granting the sovereign immunity of Germany, since it could be sued itself by the victims of the Italian wars in the Balkans, in Libya, and in Ethiopia. 
limitations to the immunity rule in case of damages or injuries caused by the activity of armed forces in the territory of the forum State" (para. 5.1) is at odds with para. 69 of the ICJ decision, whereby "the inclusion in the Convention of Article 12 cannot be taken as affording any support to the contention that customary international law denies State immunity in tort proceedings relating to acts occasioning death, personal injury or damage to property committed in the territory of the forum State by the armed forces and associated organs of another State in the context of an armed conflict".

Sixthly, the fact that Judgement No. 238 has, de facto, assigned the Corte Costituzionale itself with the authority to review general international rules which clearly are not "laws or other acts having the force of laws of the State or the Regions", appears prima facie inconsistent with Article 134 of the Constitution. Has the Court given compelling reasons to justify such a departure from the constitutional text? I believe it has not. When arguing against its Russel precedent, which was itself highly questionable, Judgment No. 238 equates Italian laws to general international rules, in order to state that just like the Court may review "laws" that are antecedent to the Italian Constitution (according to its Judgment No. 1 of 1956), so it may also review general international rules that emerged before the Italian Constitution. In the Court's words, "the principle set out in Judgment No. 1/1956, according to which the control of constitutionality concerns both norms subsequent to the republican Constitution and those prior to it, also applies to generally recognized norms of international law that are automatically incorporated by Article 10(1) of the Constitution, irrespective of whether they formed before or after the Constitution" (para. 2.1). Similarly, the Court asserted that it is empowered to review general international rules, and that it possesses exclusive reviewing power over them, although Article 134 of the Constitution does not mention them, on grounds that "[a]ccording to [Article 134], all laws, acts and norms that have the same legal effects as formal laws (ordinary or constitutional), but came into being through means other than the legislative process-including the aforementioned [customary international] norms - are subject to centralized constitutional review", pointing out that "[t]he scrutiny of this Court is excluded only for acts that are hierarchically below the law, and do not enjoy the same legal force as the law" (para. 2.1). However, there is nothing in the Constitution that justifies the equation made by the Court, and the implications that the Court has drawn therefrom. It is a fact that Article 10(1) of the Constitution does provide for no restriction to the entrance of generally recognized rules of international law; that Article 134 of the Constitution provides for no competence of the Corte Costituzionale (still less an exclusive competence) to review such rules; that no domestic "mirror rule" (as the referring court had proposed, following 
a doctrinal theory of the past) reproducing such rules exists domestically; and that the application of the law (including international law) in Italy is "naturally" reserved to the ordinary courts. As a result, the view that suits best the text of the Constitution is simply that Article 10(1) of the Constitution renders all general international rules applicable within the domestic legal system, without filters, and that only after their entrance in such system, an issue of ranking and of the possible prevalence of supreme constitutional principles may arise. This is for the ordinary courts to be assessed, including the Corte di Cassazione for the task of ensuring uniformity of jurisprudence among the lower courts, with effects limited to the instant cases. The ordinary courts may well raise questions before the Corte Costituzionale as to whether a certain constitutional principle is "fundamental" for the purposes of assessing whether a given general international rule is to be applied domestically.

Seventhly, by endorsing a "non-entrance" (rather than "non-application") version of the "counter-limits" doctrine, ${ }^{33}$ Judgement No. 238 appears to be aimed at pushing back "at the door" those general international law rules which may be in contrast with fundamental constitutional principles. ${ }^{34}$ In doing so, it nonetheless presumes that such rules have already "entered" the domestic legal order (although how they have supposedly done so, remains unclear). In fact, the Court seems to assume that the international rule does enter the Italian legal system where it describes "the envisaged conflict between the norm of international law (a norm that is hierarchically equivalent to the Constitution through the referral of Article 10, para. 1 of the Constitution) incorporated and applied in the domestic legal order, as interpreted in the international legal order, and norms and principles of the Constitution" (para. 3.1, emphasis added). Hence the international rule does enter the domestic system and it is here that it has a constitutional rank. At the same time the Court declares that

33 It is worth noting that, from a linguistic viewpoint, in the Russel Judgment (cit. supra note 14) the Court stated that the automatic reception of general international law by Article 10(1) of the Constitution "could in no way prevent" the violation of fundamental principles of the Italian constitutional order by general international rules subsequent to the Constitution, without specifying whether this occurred as an effect of its domestic precedence, or rather as an effect of its failure to enter the legal system. Conversely, in the Baraldini Judgment (cit. supra note 14), the Court spoke expressly of a "limit to the entrance" (limite all'ingresso) of general international rules into the Italian legal system, should such rules be in contrast with supreme constitutional principles. In the Milde Judgment (cit. supra note 14), the Corte di Cassazione observed, without further details, that the Italian constitutional order "conforms $[\ldots]$ on condition $[\ldots]$ " that general international rules do not entail a violation of fundamental constitutional principles.

34 PINELLI, "Decision no. 238/2014 of the Constitutional Court: Between Undue Fiction and Respect for Constitutional Principles”, Questions of International Law, 2014, p. $38 \mathrm{ff}$. 
it "cannot exercise such a control" of constitutionality since "[i]nternational custom is external to the Italian legal order" (para. 3.1, emphasis added), thus assuming that its review is possible inasmuch as the international rules is no more "external". This means, however, that the international rule has somehow entered the domestic legal system. The idea that the Court merely verifies whether general international rules are in conflict with fundamental principles of the Constitution before entering the Italian legal system (and hence regardless of their characterization as "laws and enactments having force of law issued by the State and Regions" under Article 134 of the Constitution) is very unpersuasive. When the Court prevents incompatible international rules from "entering" the Italian system, it operates a constitutional review of rules other than "laws and enactments having force of law issued by the State and Regions", as the Court scrutinizes their compatibility with the other relevant constitutional rules as though they had already entered the Italian system, and on this very basis it is entitled to examine them as legal rules. In other words, the constitutional review takes place anyway, although it is "hidden" behind the idea that the relevant international rule has not entered the system. This "picture of non-entrance" is a fiction that leads to many incongruities. Besides, the Corte Costituzionale's extension to general international law of the "counter-limits" doctrine as applied to treaties, including EU law, is even less persuasive when considering the different modes of reception of such international rules in the Italian legal system and the language of Article 134 of the Constitution. In fact, unlike general international law, treaties are received in the Italian legal system through ad hoc laws, which undisputedly fall under Article 134's review power of the Corte Costituzionale, and the possibility of their annulment is unquestioned, as Judgment No. 238 has done with regard to Article 1 of Law No. 848 of 1957. Conversely, general international law becomes Italian law by virtue of Article 10(1) of the Constitution, without being or becoming the content of any specific reception law. On this point, in Judgement No. 238 the Corte Costituzionale declared the referral unfounded, denying that general international rules automatically "create" identical ("mirror") domestic rules. So, the plainest answer, contrary to Judgment No. 238 , is that Article 10(1) of the Constitution allows all general international rules to "enter" the system. It is only after such "entering" that a ranking issue arises, and the courts (the ordinary courts, as clarified above) may establish whether such rules are or not in contrast with fundamental constitutional principles.

Eighthly, Judgment No. 238 has established four constitutional levels of hierarchy that allow any possible conclusion, depending on the circumstances, on top of which the possibility that "a public interest recognizable as potentially prominent" exists is capable of annulling (and ultimately discrediting) 
the "fundamental principles" themselves and their apparent precedence over general rules of international law. The Court's construction contemplates the following constitutional hierarchy: (1) "ordinary" constitutional rules, including Article 10(1) of the Constitution, which are higher in rank than any other sub-constitutional rule; (2) general international rules that are in line with the fundamental principles of the Constitution, which "enter" the domestic legal system overriding other constitutional rules; (3) general international rules that conflict with the fundamental principles of the Constitution, which do not "enter" the domestic legal system. This means that, in practice, such fundamental principles are higher in rank than such rules, which are, in turn, higher in rank than other constitutional rules. However, (4) even the fundamental principles of the Constitution may yield to "a public interest recognizable as potentially prominent" which, thus, is even higher in rank than those principles. It may be added that fundamental constitutional principles may be characterized as such by the Court in certain circumstances, but not in others. For example, the right to a court under Article 24 of the Constitution is not intended as being absolute by the Corte Costituzionale itself (but it is understood to be subject to a proportionality assessment, which varies on a caseby-case basis), nor by international tribunals. ${ }^{35}$ Furthermore, the fundamental character of the "inviolable rights" protected by Article 2 of the Constitution, while being beyond doubt, does not necessarily entail that the right to reparation as a consequence of their violation has the same character, nor that their violation requires specifically such a remedy. Judgement No. 238 has not clarified why the right to access to justice and the inviolable rights of the person are, depending on the circumstances, "more or less" fundamental or "absolute", so that at times they prevail, while they do not at others. The Court has only asserted that in the instant case the sacrifice of the victims would have been "totally disproportional". In summary, on top of this construction there is an arcane, that is the possible existence of "a public interest recognizable as potentially prominent". Moreover, between the four levels of hierarchy, there exists the possibility of applying the rules in terms of relative "supremacy" and/or "proportionality", so as to reach the results that are (rightly or wrongly) deemed to be preferable, whatever the rules in force. Briefly, the exclusive

35 In Italian jurisprudence, Article 24 has been considered to yield to the need to safeguard international relations to which the immunities are directed (Corte di Cassazione (Sezioni Unite Civili), Nacci v. Istituto di Bari del Centre international de hautes études agronomiques méditerranéennes, 8 June 1994, No. 5565). Moreover, for that matter, this is also the interpretation given by international monitoring bodies to the right of access to court laid down in human rights treaties. 
review power that the Corte Costituzionale has established with Judgment No. 238 underlies a "diplomatic" or "political" conception of international law, which is deemed to be better managed "politically" by the Corte Costituzionale alone, rather than (strictly "legally") by the ordinary courts. ${ }^{36}$

Ninthly, Judgement No. 238 did not consider whether the UN Charter can be regarded as being validly in force within the Italian legal system, given the lack of an ex ante law of authorization to its ratification in line with Article 80 of the Italian Constitution. The Court took for granted that it was, and, based on this assumption, it partially annulled Article 1 of the UN Charter's implementing law, to the extent that it implements Article 94 of the Charter, and thus violates Articles 2 and 24 of the Italian Constitution, pointing out that "the persistent validity and effect of the implementing Law No. 848 of 1957 remains firm and unquestionable in respect of the remaining part". As is well known, in the Italian legal system the domestic competence to ratify, and more generally to conclude treaties, is vested in the Head of State, with the countersignature of the proponent Minister, who shall be accountable for such ratification (Article 89 Italian Constitution), subject to, where required, the authorization of Parliament (Article 87(8) Italian Constitution). The latter, to be given "by law", is required for those international treaties that "have a political nature, require arbitration or a legal settlement, entail change of borders, spending or new legislation" (Article 8o Italian Constitution). The admission of Italy to the UN took place following an application submitted in 1947 by the then Italian Foreign Minister - at a time when the Republican Constitution currently in force was not yet effective, and an authorization to accede to the UN Charter was seemingly required by Article 3 of the Provisional Constitution adopted by Lieutenant's Decree-Law No. 98 of 16 March 1946 — and Italy's admission was accepted only in 1955, due to cross-vetoes at the UN Security Council between the two blocs led by the United States and the Soviet Union. Only on 17 August

36 In practice and in legal scholarship a compromise has been suggested, by noting that the "non-application" of the international rule may be excluded (and hence, the international rule may be applied and immunity recognized) only when Article 24 is satisfied by "equivalent" protection, that is, by other courts - either of the State entitled to immunity, or of the sending State of the diplomatic agent involved, or of the International Organization concerned-which are capable of providing a judicial protection that is equivalent to the one provided by Italian courts. In the 2012 ICJ Judgment, the ICJ excluded that under customary international law the right of the State to immunity depends on the existence of alternative effective remedies for the purposes of ensuring reparation. In Judgment No. 238, the Corte Costituzionale in fact denied any relevance to the "equal protection" test, which, while not envisaged in international law, is more objective than the "prominent interest", and may well lend itself to work as an interpretative key to Article 24, inter alia, in light of recent trends pushing towards its international acceptance. 
1957, two years after Italy's accession, the Italian Parliament issued Law No. 848 containing the "implementing order" (but not the authorization to ratification) which made the Charter operative within the Italian legal system. It is obvious that the accession of Italy to the UN Charter entailed "spending" and "new legislation"; even more obviously, the Charter had a "political nature", whatever the meaning of such a relatively indeterminate term might be. Article 46(1) of the Vienna Convention on the Law of Treaties ("VCLT"), which is generally considered declaratory of customary international law, stipulates that a "manifest [...] violation of a provision of [...] internal law regarding competence to conclude treaties [...] of fundamental importance", such as Article 8 o of the Italian Constitution undoubtedly is, is a ground of invalidity of the treaty. Article 46(2) vCLT specifies that a violation is "manifest" if "it would be objectively evident to any State conducting itself in the matter in accordance with normal practice and in good faith", that is, according to habitual practice. Was, thus, the UN Charter concluded unconstitutionally, that is, in violation of Article 8o of the Constitution? In Judgment No. 238 the Corte Costituzionale took for granted that the UN Charter was validly operative in the Italian legal system and, on this very premise, it partially annulled its implementing order in Ferrini-like circumstances. This approach is far from obvious. In legal doctrine, at least three theories have been advanced to address this issue, with quite different conclusions. ${ }^{37}$ The Corte Costituzionale itself in its previous case

37 According to one theory, the subsequent approval — provided that it is given through an "ordinary law", that is, through the same formal instrument required by Article 80 of the Italian Constitution, as it is usually the case-would cure the constitutional illegality of the treaty, and hence also its international invalidity (see conforti, Diritto internazionale, cit. supra note 13, pp. 85-87). An opposite theory argues, instead, that the admission of an ex-post curing effect amounts to encouraging the circumvention of Articles 80 and 87 of the Constitution by the Executive, and to forcing Parliament to approve the treaty at a later time, when the treaty is already in force at the international level. In support of this second theory it is also argued that the Constituent Assembly was clearly in favour of prior parliamentary authorization and of concluding the treaties falling under Article 80 "in solemn form" (see CASSESE, Diritto internazionale, Bologna, 2006, pp. 257-259). A third theory relies on internal practice and the absence of objections or conflicts of attribution by the Head of State and Parliament to advocate for a constitutional customary rule (similar to others found in other constitutional systems) that has crystallized in respect of treaties falling under Article 80 but concluded "in simplified form" (see MONACO, "La ratifica dei trattati internazionali nel quadro costituzionale, RDI, 1968, p. 641 ff.; MARCHIsIo, "Sulla competenza del Governo a stipulare in forma semplificata i trattati internazionali", RDI, 1975, p. 533 ff.; SALERNO, Diritto internazionale. Principi e norme, 5 th ed., Milano, 2019, pp. 181-183. This latter view was upheld by the Italian Corte di Cassazione (Sezioni Unite Civili), Soc. Unione Manifatture v. Ministero delle finanze, 22 March 1972, No. 867. For a fourth view, requiring that in respect of each treaty one has to check whether a constitutional customary rule capable of curing the breach of 
law has firmly ruled in favour of the absolute need for a prior authorization, pointing out that, otherwise, the implementing order itself is devoid of legal effects. ${ }^{38}$ One would have expected the Court firstly to verify whether, and on what legal basis, the UN Charter in its entirety was validly operative in the Italian legal system, with the possible answer (inferable from its previous case law, except for the possibility to put forward some new argument) that it was not legally operative because of its "original" unconstitutionality (for violation of Article 80 of the Constitution), and that consequently also Law No. 848 had no effect. Instead, the Court failed to explain the constitutional basis of "the persistent validity and effect of the implementing Law No. 848 of 1957". One reasonable meaning that can be given to the silence of the Court in this regard, and to the issue in general, is that (at least) in respect of the UN Charter there is acquiescence, and a constitutional custom has formed capable of curing the original violation of Article 80, a custom that Judgment No. 238 would have reinforced. The same acquiescence may also explain why the UN Charter is by now internationally validly binding on Italy, despite Article 46 VCLT, by virtue of Article 45 VCLT. ${ }^{39}$

Finally, Judgement No. 238 has not pondered what will be, in practice, the plausible outcomes of its principled stance, that is whether Italy will have to refund Germany's payments as reparation for the violation of the ICJ ruling, in

Article 8o has emerged (and answering affirmatively as far as the UN Charter is concerned), see FOCARELLI, International Law, Cheltenham, 2019, pp. 151-152.

38 In the 1984 Medusa Distribuzione Judgment, the Corte Costituzionale explicitly excluded that the authorization to ratify a treaty concluded by the State in simplified form may be adopted ex post and be found in the implementing law. In the Court's words, "the authorization, as is framed in the Fundamental Charter, emanates from Parliament necessarily before [...] the treaty is ratified", so that "it cannot but be effective for the implementing order, where, as it happens here, this is adopted by the lawmaker [...] in the absence of a prior authorization of ratification" (Corte Costituzionale, Srl. Medusa Distribuzione v. Ministero del turismo e dello spettacolo, 19 December 1984, No. 295, para. 6). Eventually, in the 2004 Regione EmiliaRomagna Judgment the same Court pointed out that, in the abstract, the implementation by the Italian Regions of a treaty concluded by the State in simplified form in violation of Article 8 o of the Italian Constitution, would be unlawful, since, inter alia, in such a case "the treaty $[. .$.$] is certainly devoid of any effect in the Italian legal system" (Corte Costituzionale,$ Presidente del Consiglio dei Ministri v. Regione Emilia-Romagna, 6 December 2004, No. 379, para. 3). It seems thus that, according to the Court, the law implementing a treaty concluded in breach of Article 80 for lack of prior parliamentary authorization, neither cures the constitutional illegality (and, consequently, international invalidity) of the treaty, against the first theory above (see previous note), nor produces internal legal effects.

39 "A State may no longer invoke a ground for invalidating [...] a treaty under articles 46 to $5^{\circ}[\ldots]$ if $[\ldots]$ it must by reason of its conduct be considered as having acquiesced in the validity of the treaty". 
which case Italian and not German taxpayers will have to pay. ${ }^{40}$ Furthermore, the suggestion put forward by some Italian scholars that, in order to guarantee the principle of reparation, Italy itself could repay the victims on behalf of Germany, ${ }^{41}$ not only would be, at the very least, peculiar, but it would also establish a precedent-once it is framed as a general interpretation of the Constitution, rather than a political arrangement made on a case-by-case basis - entailing that Italy would potentially have to repay all the victims of any war at any time (or at least since Second World War) for what today (and unpredictably tomorrow) could be considered to be serious human rights violations committed by another State against victims seizing the Italian courts. In the meanwhile, the outcome of Judgment No. 238 is that Italy is still violating both international law and the ICJ decision. It is controversial whether Germany may appeal again to the ICJ, that is, whether the Court is competent to hear cases concerning the defiance of its own judgments, when considering that under Article 94 of the UN Charter provides for a specific procedure to this end, before the Security Council. ${ }^{42}$

In summary, the Corte Costituzionale evidently was resolved to give, at any cost, a moral ("symbolic", according to some scholars) lesson to the world-a fairly tragicomic one, if one considers that it comes from a State that, at the time of the facts concerned by Judgement No. 238, was noticeable for opportunistically trying its best to jump on the bandwagon, first and foremost of Nazi Germany. Truth is that Judgement No. 238 is underlain by an "internalist" theoretical-pragmatist approach to international law, which not only lacks any theoretical foundation (since it does not explain why international law exists and, qua "international", what it is for), but which also tends, notwithstanding its intentions, to justify currently popular "souverainist" positions based on the (doubtful) premise that national law might be "more enlightened" than international law is. ${ }^{43}$

40 See коцв, "The Relationship between the International and the Municipal Legal Order: Reflections on the Decision No. 238/2014 of the Italian Constitutional Court", Questions of International Law, 2014, p. $14 \mathrm{ff}$.

41 Including, recently, by GAJA, "Alternative ai controlimiti rispetto a norme internazionali generali e a norme dell'Unione Europea", RDI, 2018, p. $1043 \mathrm{ff}$.

42 In favour of this possibility, see BONAFÉ, "Et si l'Allemagne saisissait à nouveau la Cour Internationale de Justice?", Ordine internazionale e diritti umani, 2014, p. 1049 ff. Instead, CONFORTI, "La Corte costituzionale e i diritti umani misconosciuti sul piano internazionale" (cit. supra note 13) seems to oppose it.

43 See supra note 13. The approach mentioned in the text was followed by Conforti, and it is premised on the 19th-century theory which considered international law as the result of the "self-limitation" of individual States, and on the notion that international law "becomes" law proper only when it is received in domestic legal systems, that is, translated into domestic 
As I recently discussed elsewhere, it seems that the Italians in general share a certain tension between legal disenchantment and engagement. They expect the law to bring order and justice and, at the same time, they see the law as the typical formal strategy of the strongest or, in any event, a technique to level people out artificially, which does no justice to people's inner peculiarities. ${ }^{44}$ My personal answer to this tension is a realist-constructivist approach to international law, on which very few notes will suffice here, before concluding, based on this perspective, my analysis of Judgment No. 238.45

Realism demands that existing legal rules are identified as those rules which, on average, work in practice in a society, according to the generality of their addressees as a whole. It avoids pure speculation and moralism and identifies the law in force on the basis of objective, and objectively communicable, data. Constructivism implies that values, while not necessarily coincident with the existing rules, are essential to guide the struggle for a better (or more just) international law tomorrow. It explains the crucial role of values as important and indeed indispensable dynamic factors of change in the law, towards justice. This process is already now part of international law. The dynamics of international law is no less important than its statics: international custom has to be changed, and its change is only possible by deviating from the law in force. Domestic courts, especially supreme courts, may trigger

law, otherwise representing solely an Austinian "positive morality" (CONForTi, Diritto internazionale, (cit. supra note 13, pp. 9-10). Conforti, thus, proposed that respect for the "fundamental constitutional principles of the State" could be considered, "in the light of a modern and realistic vision of international law", as a reason to justify an internationally unlawful act that is endorsed by international law itself (except for violations of jus cogens, and at least "when such a rupture [between constitutional fundamental principles and international law] is ascertained by the supreme constitutional organs of the State" (ibid., p. 400, author's translation). It goes without saying that this suggestion has no basis whatsoever in international law, according to Article 3 of the Articles on the Responsibility of States for Internationally Wrongful Acts adopted by the International Law Commission in 2001 in respect of the breach of any international rule, and to Article 27 VCLT with specific regard to the law of treaties, and it lends itself to potentially irreconcilable views as to which ones among the different States' constitutional fundamental principles may be deemed "acceptable" by all States as a common cause of justification for an internationally wrongful conduct (unless the same stance is argued in terms of the possibility that all States may uphold this new trend in the future, which is the view taken here).

FOCARELli, "The Concept of International Law: The Italian Perspective", in HILPold (ed.), European International Law Traditions, Cham, 2020, pp. 97-136.

45 FOCARELLI, International Law as Social Construct (cit. supra note 5), pp. 1-140; ID., Trattato (cit. supra note 5), pp. 1-53. 
such a process by applying domestic law, in particular higher-in-rank constitutional law, rather than international law. This deviation is indeed a violation of international law, since domestic law cannot be invoked to justify a violation of international law, but (when it is genuine) it is somewhat different and to be distinguished from "ordinary" violations of international law, to the extent that it is aimed at changing the latter (allegedly) for the better (of all). This difference has to be argued: e.g. the courts have to show that a "promotional" violation is "necessary" to change the law towards justice, as any State and its organs could reasonably recognize.

This realist-constructivist approach is neither "positivist" nor "naturalist" in essence: it searches for empirically determinable rules, to find out what is the "law" that effectively works in society. At the same time, it conceives of the law as that which its addressees as a whole believe it to be, thus assuming that beliefs are constantly challenged and overtaken by other beliefs, and that a better law in the future is pursued through actual behaviour today. Action is as important to the law as is knowledge. Just as the existing law is the result of past struggles, current struggles are the basis of future law. Law statics and law dynamics should be argued together.

The realist-constructivist approach does not coincide either with the typical positivist dichotomy "lege lata versus lege ferenda". Realist means that the law "in force" is the one that its addressees as a whole believe to be their law. This law should be visibly recognized and complied with on average, it is not an ideal law from the standpoint of this or that enlightened scholar and his/her personal view of justice. It is the law that "works" among its addressees taken as a whole, according to their viewpoint. Consequently, the law in force may be of any kind: "divine", "natural", "positive", "magical", "rational", etc. Traditional theoretical categories are hardly relevant. What counts is the belief shared by people. In this sense, law is always mythic, and "realism" does not exclude divine or natural law, nor does it necessarily coincide with positive law. In turn, constructivism means that the struggle for (more, less, just) law is part of the process of law-making and unmaking, not a possible or merely theoretical appendix.

Nor does the realist-constructivist formula coincide with the dichotomy "progressivism versus conservatism". Unlike what might be expected at first sight, the realist component may well be "progressive" and the constructivist component (as materialised by society as a whole) may well be "conservative" or even "reactionary", according to the meaning that those who believe in these terms assign to them. Realism may well be the sounder starting point for humanitarian action, whereas humanitarian struggle may well conceal the pursuit of private advantage. 
Turning to Judgment No. 238, the Ferrini jurisprudence had, and still has, no basis in customary international law. States have a right to jurisdictional immunity even when accused of serious human rights violations. This is what (both domestic and international) courts other than the Italian ones, have stated thus far, including most lately the US Supreme Court. Italian courts could not deny immunity to Germany on the basis of international law. Their doing so, on the basis of Judgment No. 238 , is a manifest and continued violation of international law. This is my "realism". It is, however, perfectly comprehensible that immunity should hopefully be denied in cases of serious violations of human rights. How could such a rule come to being, once it has been established that it does not exist at present? By triggering a rule-making process. Italian courts could reach their conclusions immediately on the basis of Italian (constitutional) law, rather than on the basis of international law, and expect the courts of other States to follow suit in order for a new rule to come into existence. Since the 2004 Ferrini decision, I have suggested that this was the path to take. This had to be done before the ICJ Judgment, not after, and it had to be done by "tailoring" the new rule (according to an appropriate interpretation of the Italian Constitution) in such a way that it could reasonably be accepted by others. By way of example, for an exception to be generally reasonably acceptable, it should only apply to present and future cases, and to well-determined human rights violations, as well as to all States equally, and in cases where the victims have no alternative judicial remedies available, so as to avoid, respectively, unlimited retroactivity, and the denial of immunity with respect to minor human rights violations, or against "selected" States, or when the victims may obtain redress otherwise. ${ }^{46}$ In other words, Italian courts should "construct" the new rule by showing that it would be reasonable for all to accept it, on the basis of its justness. In this sense, I do understand the "struggle" of most Italian scholars in favour of the Ferrini case law, yet it remains a struggle, and as such, however valuable, it is not the law. By insisting that Ferrini was the law, the Italian courts have simply failed to explain why the desired rule was potentially acceptable to others, and the Italian position has proved so far merely unilateralist. This is not to say, of course, that international law might not change in the future in accordance with the Ferrini case law.

46 FOCARELLI, International Law as Social Construct (cit. supra note 5), pp. 433-437. 
The only plausible legal perspective that justifies the Ferrini jurisprudence is a dynamic one. However, Judgment No. 238 has made no significant argumentative contribution in this respect, it has simply repudiated a finding that had already been made at the international level, by the principal judicial organ of the United Nations. A breach of international law for transformative purposes is plausible in the absence of a finding by an international court, not thereafter. As a result, according to the Corte Costituzionale, Italy has now to allow all relevant pending domestic proceedings to go ahead, in manifest and objective breach of international law, ad infinitum. The Corte Costituzionale has substantially failed to argue the plausibility of the change in the international law in force that it wished to promote for the future. So far, no other supreme court, including, lately, the US Supreme Court, has followed suit. To realistically and successfully take its intended big leap, the Italian position deserved a sounder theoretical analysis of international law, and of the world system within which international law is meant to work. Instead, the Italian Corte Costituzionale seemed satisfied with "pontificating" to the rest of world from a standpoint of apparent moral superiority, without even marginally touching upon the enormous implications of its ruling. It is also currently forcing lower courts to align themselves to a paradoxical, continued reinforcement of Italy's internationally unlawful conduct, the worst lesson to impart from what ends up (unjustly) appearing as a "typically Italian" opportunist proclivity. 